\title{
Improving Reading Comprehension of the Content Novel Rembulan Tenggelam di Wajahmu By Tere- Liye of Students English Literature at Second Semester Musamus University
}

\author{
$1^{\text {st }}$ Marnina* \\ Department of English Literature \\ Universitas Musamus \\ Merauke, Indonesia \\ marnina@unmus.ac.id
}

\author{
$2^{\text {nd }}$ Margaretha Febriany Narahawarin \\ Department of English Literature \\ Universitas Musamus \\ Merauke, Indonesia \\ narahawarin_fkip@unmus.ac.id
}

\author{
$3^{\text {rd }}$ Natalia Manuhutu \\ Department of English Literature \\ Universitas Musamus \\ Merauke, Indonesia \\ manuhutu_fkip@unmus.ac.id
}

\begin{abstract}
This research aims to improving reading comprehension of the content Novel Rembulan Tenggelam di Wajahmu by Tere-Liye of students English Literature at second semester Musamus University.This research is a qualitative research and is carried out in Musamus University. The subjects of this research were second semester students English Literature Department consists of 18 students. The instruments and data collection techniques, namely tests and observations. Data analysis in this study uses qualitative data analysis techniques and quantitative analysis which aims to determine the level of students' reading comprehension of the content novel. Based on the results show that the improving reading comprehension of the content novel of students English Literature at second semester Musamus University in the aspect of the able to understand the content of novel in the good category with a value of 66, the aspect of the understanding vocabulary in the poor category that is 51 , and in the aspect of the conclude the content of novel in the fair category that is 61 . The low ability to reading comprehension that is learning process has been dominated by the teacher. Every time the teacher just learn reading, they only ask students to read and then finish the practice questions. The learning process like this results that students feeling bored and unenthusiastic in learning process.
\end{abstract}

Keywords: reading comprehension, novel rembulan tenggelam di wajahmu

\section{INTRODUCTION}

Reading is interactive; the involvement of the reader with the text depends on the context. Basically, reading is a process. Burn, Roe and Ross as quoted by incorporate the reading process into reading activities that the reading activity consists of the reading process and reading products [1]. The reading process is the act / activity of reading, while the reading product is the communication of the thoughts and feelings of the writer to the reader.

Meanwhile, reading is a process carried out and used by readers to obtain the message to be conveyed by the writer through the media of words / written language [2]. Reading is a complex process, in the process of reading involved various internal factors and external factors of reading [3].
Internal factors include intelligence (IQ), interests, attitudes, talents, motivation and reading goals, while external factors include means of reading, reading texts, environmental factors or socioeconomic background factors, reading habits and traditions.

To understand a reading, one must have a reading comprehension technique. Devine as quoted by [4] provides a definition of reading comprehension is the process of syntax, semantic, and rhetorical information contained in written texts arranged in the mind of reading by using public knowledge possessed, cognitive abilities and reasoning. Next the reader formulates the hypothesis as an embodiment of the explicit message of the text. This definition explains that in understanding the reading, the reader builds new knowledge by linking reasoning and knowledge already known.

Reading is a process that is carried out and used by readers to obtain the message to be conveyed by the author through the media of words or written language [2]. People who love to read will gain new knowledge and insights that can increase their intelligence so that they are better able to answer challenges in the future. Reading will be increasingly important in complex community life because every aspect of life involves reading. Farr, quoted by [1], states, "reading is the heart of education" which means reading is the heart of education. People who read often, their education will advance and they will have broad insights.

By reading we can find out the whole world and our thinking patterns will develop. Reading is an activity to understand and interpret symbols or signs / writings that are meaningful so that the message conveyed by the writer can be received by the reader. Reading comprehension is a person's ability to reconstruct the message contained in the text that is read by connecting knowledge possessed to understand the main idea, important details, and the whole understanding and remember the material read.

Reading deals with ability of people in articulating word in a written text and understanding meaning that is conveyed in it. Reading comprehension means understanding of thing that we read, how we get much information from the reading 
and how we understand our reading well. We perform a deep and full understanding, arrived at by close, accurate and imaginative reading of passage set [5].

[6]States that reading is a complex conscious and unconscious mental process in which the reader uses a variety of strategies to reconstruct the meaning that the author is assumed to have intended, based on data from the text and from the reader prior knowledge.

So, reading comprehension is the ability to read text, process it and understand its meaning. An individuals ability to comprehend text is influenced by their traits and skill, one of which is the ability to make inferences.

Literature is a creative activity, a work of art [7] Literature is also considered as an imaginative, fictitious, and innovative work. Etymologically literature, literature itself is defined as a tool for teaching, instruction manuals, or instruction manuals. Meanwhile, literary works are a world of imagination and fiction [7]. Literary works are fictional worlds whose reality or facts have been made in such a way by the author. Such a view is a correct view according to positivists. Fiction itself is interpreted as the result of imagination, fiction, or wishful thinking.

Through a novel, the author can illustrate that each person has his character, such as humorous, possessive, or temperament, etc. When we read a novel, various kinds of feelings will emerge such as happy, sad, angry, sorry, tense, even bored when looking at stories about life and the stories of each character (character) in the novel. This is consistent with the assumption that literature was created not in a cultural.

In general, literary work is a work that is formed from an author's imagination. It is also an expression of the images and events of daily activity directly or indirectly. Literary works have function to entertain or teach something to the readers. The function of this literature can be found in any kind of literary works. There are many works of literature such as novels, poetry, prose, movie script and many more.

A novel is one of the literary works and the novel is a fictional story in the form of writing or words and has intrinsic and extrinsic elements. a novel usually tells about human life in interacting with the environment and each other. In a novel, the author tries his best to direct the reader to the depictions of the reality of life through the stories contained in the novel.

According to Kramer, (in Khotimah, 2015: 6) the form of a novel is concentration, the concentration of life at a time in a decisive crisis [8]. Meanwhile, in terms of novels included romance, because romance is only a novel term for the era before World War II in Indonesia [9]. Furthermore according to Sumarjono (in Khotimah, 2015: 6) said that the novel is a product of society. Novels are in society because they are formed by community members based on emotional and rational urges in society [8].

A novel is a long essay and tells a story / event and is an in-depth description of a theme that is expressed through the story of a person's life with the people around him. The story moves from one scene to another and from one place to another with quite a long time.

Based on observations in class during the learning process of Basic Reading Skills for Second Semester
Students in English Literature at Musamus University, it was found that lack of student ability to understand reading material. Beside that students find it difficult to interpret a reading, because there are still many vocabulary that do not yet know the meaning, besides that students also find it difficult to determine the main idea of a reading, and are unable to read simple words or sentences correctly. The research is expected to help the students learning about reading comprehension, they can enjoy to learn English especially reading by using novel and also the students became the center of teaching learning process by involving themselves through the participation in class.

Based on the explanation above, the researcher hopes that novel is helpful in teaching reading and will be improve the students' reading ability. So, researcher would like to take a research " Improving reading comprehension of the content novel "Rembulan Tenggelam di Wajahmu by Tere Liye of students English Literature at second semester Musamus University.

\section{RESEARCH METHODS}

This research includes qualitative research. Qualitative research is a planned and systematic activity to study and interpret the behavior of certain people, events or places in detail and depth. The subject of the research the students at Musamus University at second semester Academic year $2019 / 2020$. The number of subject is 18 students take purposively sampling.

The research activities began with preparation and ended with the preparation of the report. The planning stage is carried out by monitoring the state of the students to be examined and preparing the instruments. There are 2 instruments used, namely test and observation sheet. While the implementation phase is observation and test. The researcher provides observation sheets to determine the state of the class at the time the learning takes place and field notes to record all important information related to the data needed, while the test is carried out after the learning process 2 times.

While the instrument in data collection in the form of tests and observations, the test given was administered to get the data of the students' subsequent reading comprehension or their achievement after the treatment.

Indicator component of test instruments for reading comprehension skills using novels are: students are able to discovering main idea, understanding vocabulary, conclude the content of reading. Observations were doing to find out the actual situation that occurred during the learning process. The observation aimed to get the overview of classroom activity and interaction related to reading comprehension by used novel.

Based on the fact, the data analysis in this study used qualitative data analysis techniques. In addition to qualitative analysis, researcher also conduct quantitative analysis that aims to determine the level of students' ability to read comprehension using statistical formulas to describe the results of research, with this analysis can be seen the average score obtained from the test results, then classify the scores obtained by students by calculating the percentage level students' ability. According to Arikunto (2009: 35) to determine the level of students' ability to read comprehension 
expressed based on the following score weights are very good, good, fair, poor, very poor [10].

\section{RESULTS AND DISCUSSION}

The data have been obtained from the instruments in the form of test and observation sheets. The instruments was given to the students at second semester of English Literature Department Musamus University as the subjects of this research that consist of 18 students.

\section{A. Result}

Based on the data obtained from the results of tests of understanding reading comprehension the contents of the novel it will be described below.

TABLE I. ThE RESUlt OF READING COMPREHENSION OF THE CONTENT NOVEL REMBULAN TENGGELAM Di WAJAHMU

\begin{tabular}{|c|c|c|c|c|}
\hline No & Name & $\begin{array}{c}\text { Able to } \\
\text { understand } \\
\text { the content } \\
\text { of novel }\end{array}$ & $\begin{array}{c}\text { Understanding } \\
\text { vocabulary }\end{array}$ & $\begin{array}{l}\text { Conclude the } \\
\text { content of } \\
\text { novel }\end{array}$ \\
\hline 1 & ISF & 60 & 33 & 83 \\
\hline 2 & BJED & 35 & 33 & 33 \\
\hline 3 & ZDD & 70 & 78 & 50 \\
\hline 4 & ANRD & 70 & 67 & 50 \\
\hline 5 & AKA & 70 & 67 & 33 \\
\hline 6 & PIAA & 65 & 33 & 50 \\
\hline 7 & MA & 55 & 44 & 67 \\
\hline 8 & MRA & 60 & 33 & 83 \\
\hline 9 & ALA & 80 & 56 & 83 \\
\hline 10 & $\mathrm{ZA}$ & 90 & 56 & 83 \\
\hline 11 & AW & 70 & 67 & 50 \\
\hline 12 & JA & 50 & 22 & 50 \\
\hline 13 & RNA & 80 & 67 & 83 \\
\hline 14 & LDMA & 60 & 22 & 50 \\
\hline 15 & $\mathrm{CPA}$ & 90 & 78 & 50 \\
\hline 16 & MZA & 70 & 44 & 50 \\
\hline 17 & SA & 70 & 78 & 83 \\
\hline 18 & HYA & 50 & 44 & 66 \\
\hline \multicolumn{2}{|c|}{ Score } & 1195 & 922 & 1097 \\
\hline \multicolumn{2}{|c|}{ Mean } & 66 & 51 & 61 \\
\hline
\end{tabular}

Based on the data above it can be seen that the highest value students are able to achieve in category able to understand the contents of novel are 90, while the lowest are 35 , in category understanding vocabulary are 78 , the lowest are 22 , and conclude the content of reading are 83, while the lowest are 33 . When viewed from the category of the ability to understand the contents of the reading of students the most in the good category, which was achieved as many as 4 students $(22 \%)$, while at least in the category of very little achieved by 1 student $(2,9 \%)$.

The category of understanding vocabulary of students was in the good category, which was achieved by 3 students (17\%), while none of the students gets in the excellent category, and the category of conclude the content of novel 6 students $(33,3 \%)$ while at least in the category fair level no students reach it.
TABLE II. CATEGORY OF ABLE TO UNDERSTAND THE CONTENT OF NOVEL

\begin{tabular}{|c|c|c|c|}
\hline No & Category & F & \% \\
\hline 1 & Very Good & 4 & $23 \%$ \\
\hline 2 & Good & 6 & $34 \%$ \\
\hline 3 & Fair & 4 & $23 \%$ \\
\hline 4 & Poor & 3 & $17 \%$ \\
\hline 5 & Very Poor & 1 & $3 \%$ \\
\hline \multicolumn{2}{|c|}{ Total } & 18 & 100 \\
\hline
\end{tabular}

Based on the table above, it can be seen that able to understand the content of novel is in the good category 6 students $(34 \%)$, while in very poor category 1 student $(3 \%)$. There are 4 students $(23 \%)$ were in very good category, 4 students $(23 \%)$ were in the fair category and 3 students $(17 \%)$ were in the poor category.

TABLE III. UNDERSTANDING VOCABULARY

\begin{tabular}{|c|c|c|c|}
\hline No & Category & F & $\%$ \\
\hline 1 & Very Good & 0 & 0 \\
\hline 2 & Good & 7 & $39 \%$ \\
\hline 3 & Fair & 2 & $11 \%$ \\
\hline 4 & Poor & 3 & $17 \%$ \\
\hline 5 & Very Poor & 6 & $33 \%$ \\
\hline \multicolumn{2}{|c|}{ Total } & 18 & 100 \\
\hline
\end{tabular}

Based on the table above, it can be seen that understanding vocabulary is in the good category 7 students $(39 \%)$, while in very poor category 6 student $(33 \%)$.None of students $(0 \%)$ were in very good category, 2 students $(11 \%)$ were in the fair category and 3 students $(17 \%)$ were in the poor category.

TABLE IV. CONCLUDE THE CONTENT OF NOVEL

\begin{tabular}{|c|c|c|c|}
\hline No & Category & F & \% \\
\hline 1 & Very Good & 6 & $33 \%$ \\
\hline 2 & Good & 2 & $11 \%$ \\
\hline 3 & Fair & 0 & 0 \\
\hline 4 & Poor & 8 & $45 \%$ \\
\hline 5 & Very Poor & 2 & $11 \%$ \\
\hline \multicolumn{2}{|c|}{ Total } & 18 & 100 \\
\hline
\end{tabular}

Based on the table above, it can be seen that conclude the content of novel is in the good category 2 students $(11 \%)$, while in very poor category 2 student $(11 \%)$. None There are 6 students $(33 \%)$ were in very good category, none of the students were in the fair category and 8 students (45\%) were in the poor category.

\section{B. Discussion}

From the results of tests that have been conducted, it is known that the reading comprehension of the content novel second semester students English Literature in the aspect of the able to understand the content of novel there are $6(34 \%)$ students who are able to reach the good category, the average able to understand the content of novel are 66 categorized in 
good category, from these results it can be seen that able to understand the content of novel, the students are able to understand the content of novel.

In the aspect of understanding vocabulary, most of the students are in the good category, there are $4(23 \%)$ students. But overall the values of the understanding vocabulary are 51 , in categorized poor. This is because students are focused at the beginning of the sentence, even though finding understanding vocabulary is not only at the beginning of the sentence but can be in the middle of the sentence and at the end of the sentence.

In the aspect of conclude the content of novel most of students in the category poor there are 7 students. The overall score 61 in fair category. Most of students in the category is poor category because of lack of students' knowledge, how to deduce the contents of the reading, other than that in the learning process students are not told what conclusions are. This makes it difficult for students to conclude the reading content.

From the three aspects of students' reading comprehension, it can be seen that overall the aspects of ability that are in the lowest category that is aspects of the able to understand the content of novel. The low ability to reading comprehension that is learning process has been dominated by the teacher. Every time the teacher just learn reading, they only ask students to read and then finish the practice questions. The learning process like this results that students feeling bored and unenthusiastic in learning process.

Many factors affect students' reading comprehension ability. There are students quick to understand and there are also students long to understand what has been taught. Besides that, students' attitudes and interests also influence reading comprehension skills.

People who read a lot will get more knowledge compared to people who rarely or never read. Through this knowledge, people can re-communicate information in oral or written form. In other words reading can help someone to improve their communication skills in other forms. Reading ability is the speed of reading and overall understanding of content [11].

\section{CONCLUSION}

Based on the research results obtained it can be concluded that reading comprehension ability in the aspect of the able to understand the content of novel in the good category with a value of 66 , the aspect of the understanding vocabulary in the poor category that is 51 , and in the aspect of the conclude the content of novel in the fair category that is 61 , but individually varies on aspects that able to understand the content of novel is in the good category 6 students $(34 \%)$, while in very poor category 1 student $(3 \%)$.There are 4 students $(23 \%)$ were in very good category, 4 students $(23 \%)$ were in the fair category and 3 students $(17 \%)$ were in the poor category.

On aspect understanding vocabulary is in the good category 7 students $(39 \%)$, while in very poor category 6 student $(33 \%)$.None of students $(0 \%)$ were in very good category, 2 students $(11 \%)$ were in the fair category and 3 students $(17 \%)$ were in the poor category. On aspect conclude the content of novel is in the good category 2 students $(11 \%)$, while in very poor category 2 student $(11 \%)$.
None There are 6 students (33\%) were in very good category, none of the students were in the fair category and 8 students $(45 \%)$ were in the poor category.

From the three aspects of students' reading comprehension, it can be seen that overall the aspects of ability that are in the lowest category that is aspects of the able to understand the content of novel. The low ability to reading comprehension that is learning process has been dominated by the teacher. Students feeling bored and unenthusiastic in learning process.

The result of the students' interest in the learning reading by using novel that most of students' respond interest.

\section{ACKNOWLEDGMENT}

This study was conducted and finished by the support of Rector of Musamus University and the Dean of Faculty of Teacher Training and Education of Musamus University, so the researchers convey gratitude for them for the support both material and spiritual.

\section{REFERENCES}

[1] Dalman, Keterampilan Membaca. Jakarta: Rajawali Pers, 2014.

[2] H. G. Tarigan, Membaca sebagai Suatu Keterampilan Berbahasa, Edisi Revi. Bandung: Angkasa, 2008.

[3] Nurhadi, Membaca Cepat dan Efektif. Bandung: Sinar Baru Algensindo, 2008.

[4] Nurhadi, Bagaimana Meningkatkan Kemampuan Membaca? Suatu Teknik Memahami Literatur yang Efisien. Bandung: Sinar Baru Algensindo, 2004.

[5] Panel Nasional Reading, Explaining Reading a Resource for Teaching Concept, Skills and Strategies. New York London: The Guilford Press, 2000.

[6] B. S. \& J. L. Mikulecky, More Reading Power. The Guardian, 2000.

[7] Susanto, Pengantar Kajian Sastra. Yogyakarta: CAPS, 2016.

[8] K. Khotimah, "Karakter Tokoh Utama Dalam Novel Surat Kecil Untuk Tuhan Karya Agnes Davonar," UNMUS, 2015.

[9] J. Arifin, B.; Asnidar.; Sabri.; Johan, Y. \& Udin, Sastra Indonesia (Lama, Baru, Modern). Bandung: Lubuk Agung, 1986.

[10] S. Arikunto, Prosedur Penelitian: Suatu Pendekatan Teori dan Prakteknya. Jakarta: Rineka Cipta, 2009.

[11] D. P. Tampubolon, Kemampuan Membaca Teknik Membaca Efektif dan Efisien. Bandung: Angkasa, 2007. 